Special issue of the 3rd International Conference on Computational and Experimental Science and Engineering (ICCESEN 2016)

\title{
Local Scour around Group Bridge Pier with Different Shapes
}

\author{
M. GÜnal*, T.A. Gelmeran And A.Y. GÜNAL \\ Gaziantep University, Civil Engineering Department, Gaziantep, Turkey
}

\begin{abstract}
This study is based on laboratory experiments for computing depth of local scour around group bridge pier, considering the effects of upstream flow conditions, size of pier, median size of bed material and spacing between bridge piers on the maximum scour depth and scour pattern around bridge piers. The study was conducted using a physical hydraulic model for bridge piers, operated under clear-water condition and using uniform cohesionless sand as bed material. Three different models of bridge piers, having different sizes were used for showing the effect of the size on the local scour.
\end{abstract}

DOI: 10.12693/APhysPolA.132.632

PACS/topics: 92.40.GC, 92.10.WA

\section{Introduction}

The term "scour" is used to designate erosion by flowing water, resulting in undermining foundation or bank, or in lowering a stream bed below its natural or average level. Breusers et al. [1], defined scour as a natural phenomenon caused by the flow of water in rivers. Scouring has long been acknowledged as a severe hazard to the performance of bridge piers. It has long been established that the basic mechanism causing local scour at bridge piers is the down-flow at the upstream face of the bridge pier and formation of vortices at the base. Heidarpour et al. [2] and Zarrati et al. [3], identified two main classifications of local scour at bridge piers, based on the mode of sediment transport by the approaching stream, namely clear-water scour and live bed scour. Live-bed scour occurs when the scour hole is continually replenished with sediment by the approach flow [4]. Clear-water scour occurs for mean flow velocities up to the threshold velocity for bed sediment entrainment. Ismael et al. [5], carried out experiments testing a new method to reduce scour depth in front of bridge pier, by changing the position of bridge pier. In this study, upstream facing roundnosed and downstream facing round-nosed group bridge piers were tested under live-bed condition. The results show that the downstream facing round-nosed pier reduces local scour.

\section{Experiments}

Experiments were conducted in the hydraulic laboratory of civil engineering department of Gaziantep University. The employed flume is $12 \mathrm{~m}$ long, $0.8 \mathrm{~m}$ wide and $0.9 \mathrm{~m}$ deep, with glass sides and steel bottom. The test section was made with a ramp, which is located at the beginning and the end of the section. The test section is $3 \mathrm{~m}$ long and $0.2 \mathrm{~m}$ deep. The test section was filled with sediment of median particle size $d_{50}=1.45 \mathrm{~mm}$ and standard deviation $d_{50}=\left(d_{84} / d_{16}\right)^{0.5}=3.16$, and with

\footnotetext{
*corresponding author; e-mail: gunal@gantep.edu.tr
}

specific gravity of 2.65. Flume discharge was measured by magnetic flow meter, installed in the pipe system before the inlet of the channel. The scour hole and the elevation of the bed were measured by laser meter. Experiments were performed under live bed water scour regime. The discharge was measured as $58 \mathrm{l} / \mathrm{s}$ for duration of 6 hours. Two downstream-facing round nosed piers were used $(10-10 \mathrm{~cm}$ and $10-8 \mathrm{~cm})$, as shown in Fig. 1 .

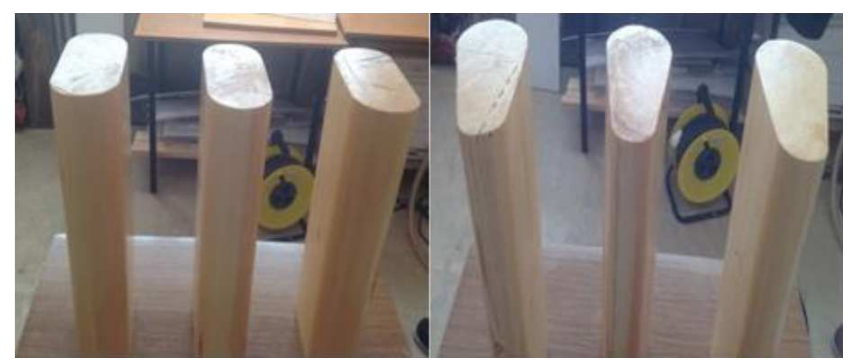

Fig. 1. Bridge pier models.

Bridge piers were made from solid wood and were located inside of the channel with different span lengths, as shown in Fig. 2.

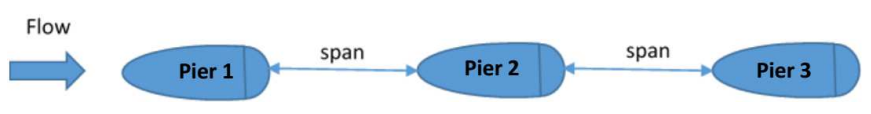

Fig. 2. Group bridge pier location in the channel.

In this study, three inlet discharges and pier models with three different span lengths are used in experiments, as shown in Table I.

\subsection{Local scour}

The scour was recorded at different time intervals using a laser range finder, to measure the maximum scour at the bridge piers. It is observed that scour formation is very rapid in the first thirty minutes and then, the rate of scour around bridge piers decreases. Maximum scour depths after six hours of continuous experiments are shown in Table II. 
TABLE I

Experimental runs and inlet discharges.

\begin{tabular}{c|c|c|c|c}
\hline \hline Model No. & Span lengths [cm] & \multicolumn{3}{|c}{ Discharge [l/s] } \\
\hline \multirow{3}{*}{$(10-10) \mathrm{cm}$} & 50 & 57 & 48 & 38 \\
& 30 & 57 & 48 & 38 \\
& 20 & 57 & 48 & 38 \\
\hline \multirow{3}{*}{$(8-10) \mathrm{cm}$} & 50 & 57 & 48 & 38 \\
& 30 & 57 & 48 & 38 \\
& 20 & 57 & 48 & 38
\end{tabular}

TABLE II

Maximum depth of scour measurements.

\begin{tabular}{c|c|c|c|c|c|c|c}
\hline \hline $\begin{array}{c}\text { Span } \\
\text { length }\end{array}$ & Discharge & \multicolumn{3}{|c|}{ Max. Scour $\left(d_{s}\right)$} & \multicolumn{3}{|c}{ Max. Scour $\left(d_{s}\right)$} \\
$S$ & \multicolumn{2}{c}{ Pier $(10-10)$} & $\mathrm{cm}$ & \multicolumn{2}{|c}{ Pier (8-10) cm } \\
\cline { 3 - 8 } & {$[\mathrm{l} / \mathrm{s}]$} & Pier 1 & Pier 2 & Pier 3 & Pier 1 & Pier 2 & Pier 3 \\
\hline \multirow{3}{*}{50} & 57 & 16.0 & 14.9 & 14.2 & 14.0 & 13.2 & 12.0 \\
& 48 & 14.2 & 13.2 & 12.7 & 13.6 & 12.9 & 11.4 \\
& 38 & 13.5 & 12.8 & 11.8 & 13.0 & 11.8 & 10.7 \\
\hline \multirow{3}{*}{30} & 57 & 15.0 & 14.3 & 13.7 & 13.4 & 12.8 & 11.5 \\
& 48 & 13.5 & 12.2 & 12.0 & 13.2 & 11.9 & 11.0 \\
& 38 & 12.4 & 11.2 & 11.0 & 12.0 & 11.0 & 10.3 \\
\hline \multirow{3}{*}{20} & 57 & 14.5 & 14.0 & 13.3 & 12.8 & 12.0 & 11.0 \\
& 48 & 13.2 & 11.8 & 11.0 & 13.0 & 11.4 & 10.8 \\
& 38 & 11.6 & 10.7 & 10.5 & 11.2 & 10.5 & 10.0
\end{tabular}

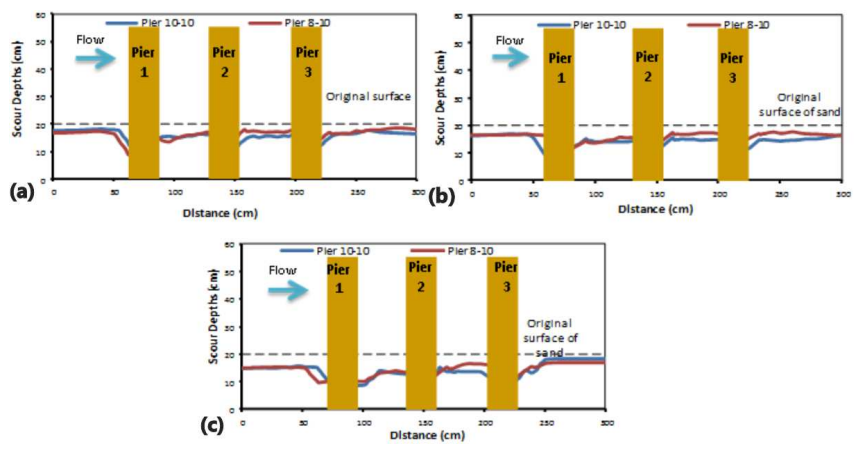

Fig. 3. Longitudinal bed profile around group of bridge piers for span length $S=50 \mathrm{~cm}$ and $Q=57$ (a), 48 (b) and $38 \mathrm{l} / \mathrm{s}(\mathrm{c})$.

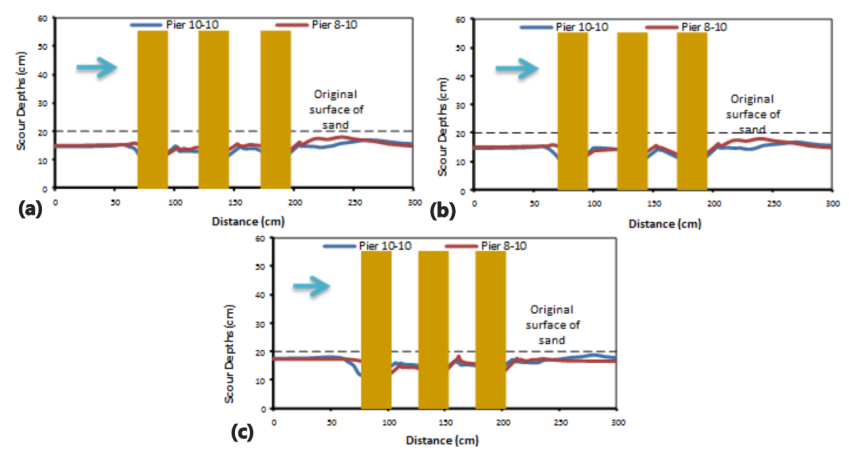

Fig. 4. Longitudinal bed profile around group of bridge piers for span length $S=30 \mathrm{~cm}$ and $Q=57$ (a), 48 (b) and $38 \mathrm{l} / \mathrm{s}(\mathrm{c})$.

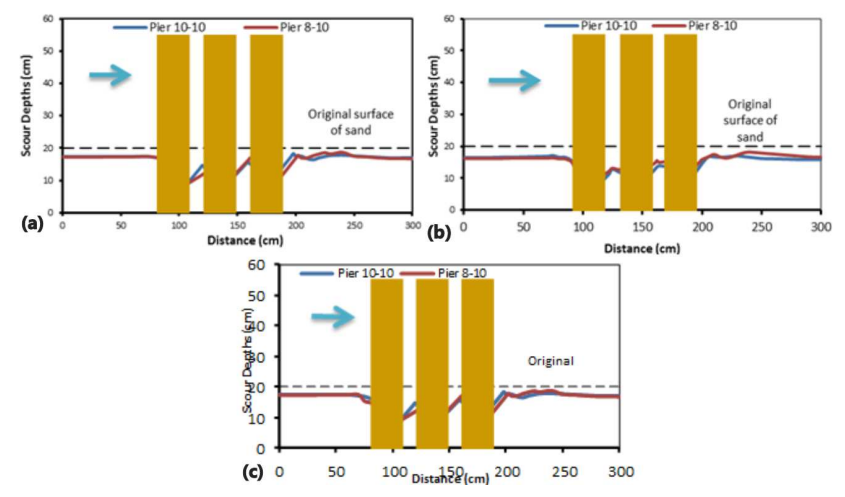

Fig. 5. Longitudinal bed profile around group of bridge piers for span length $S=20 \mathrm{~cm}$ and $Q=57$ (a), 48 (b) and $38 \mathrm{l} / \mathrm{s}(\mathrm{c})$.

The spacing between the bridge piers has a direct influence on the scouring process. That is, the scour depth decreases with increasing the spacing between the bridge piers. A set of experiments is conducted for evaluating the relationship between spacing and scour depth. It can be seen from Figs. 3-5 that the scouring process increases when span lengths increase, while the other influencing parameters, like flow depth and inlet velocity of flow, are kept constant.

\section{Conclusions}

This paper experimentally examines the application of a new method of placing group of bridge pier in the opposite direction to the flow, to reduce local scour around bridge pier. Changing the position of pier is not only effective for reducing scour, but it is also much more economic when it is compared with countermeasure techniques like riprap and slot. This experimental study was conducted in order to assess the reduction of local scour around group of bridge piers. The results of comparison between the performances of group of bridge piers under different span lengths reveal that the scour depth increases with increasing span length. We hope that the results of the present study will benefit the designers and engineers.

\section{References}

[1] H.N.C. Breusers, G. Nicollet, H.W. Shen, J. Hydraulic Res. IAHR 15, 211 (1977).

[2] M. Heidarpour, Z. Khodarahmi, S.F. Mousavi, Control and Reduction of Local Scour at Bridge Pier Groups Using Slot, in: Proc. XXX IAHR Congress, Thessaloniki, Greece 2003.

[3] A.M. Zarrati, H. Gholami, M.B. Mashahir, J. Hydraulic Res. IAHR 42, 97 (2004).

[4] S. Dey, Water Maritime Eng J. 136, 67 (1999).

[5] A. Ismael, M. Gunal, H. Hussein, Arabian J. Sci. Engin. 40, 1579 (2015). 